\title{
Introduction: Hormonal Regulation of Mammary Development and Milk Protein Gene Expression at the Whole Animal and Molecular Levels
}

\author{
Isabel A. Forsyth • Margaret C. Neville
}

Published online: 7 August 2009

(C) Springer Science + Business Media, LLC 2009

In the 1950's and 60's experimental analysis of the control by hormones of the growth and function of the mammary gland depended on two technical advances. First was the development of successful, minimally traumatic, surgical methods to remove the major endocrine organs: the pituitary, ovaries, and adrenals. Second was the supply in adequate quantities and purity of hormones for use in replacement studies, often at that time involving elaborate and lengthy procedures of purification or, for some steroids, synthesis.

During the 1930s and early 1940s, Bill Lyons at Berkeley in California, in association with Herbert M. Evans, the discoverer of growth hormone, were developing the methods of surgical ablation and replacement therapy in the Long-Evans strain of rats. By 1958, when Lyons had moved to UCSF, they had established the basic hormone complexes necessary for mammary growth and milk secretion [1]. Meanwhile, Alfred Cowie had qualified as a veterinary surgeon in Scotland by 1938 and in 1941 took up a post at the National Institute for Research in Dairying at Shinfield, Reading, U.K. He soon

\footnotetext{
I. A. Forsyth

The National Institute for Research in Dairying,

Cambridge, UK

I. A. Forsyth

The Babraham Institute,

Cambridge, UK

M. C. Neville $(\bowtie)$

Department of Physiology and Biophysics,

UCDenver School of Medicine,

Aurora, CO, USA

e-mail: peggy.neville@uchsc.edu
}

became interested in S.J. Folley's work on lactation. Encouraged by Folley, he set up the techniques of adrenalectomy and hypophysectomy in hooded Norway rats. The role of the adrenal cortex in mammary function formed the basis of his Reading University Ph.D. thesis, in 1947.

The Journal of Endocrinology paper presented here represents an unusual, particularly for the time, long distance collaboration between these two scientists, comparing the two strains of rat. They concluded that the strain requirements for mammary development and milk secretion are the same: In animals in which the pituitary gland, adrenal gland, and ovaries had been removed, growth of the mammary ducts could be restored with estrogen, growth hormone, and adrenocortical hormones. Alveolar development required the addition of progesterone and prolactin. Milk secretion could then be induced by removal of progesterone and growth hormone while prolactin and corticoids were maintained. The paper is published from their respective addresses, but, as is evident from the acknowledgments, the work was carried out at Shinfield. It is not clear whether Lyons and Cowie had met at this time, but they certainly maintained contact, mutual respect, and friendship afterwards.

Cowie and his colleagues later went on to determine the complex of hormones necessary to initiate and to maintain the secretion of milk in the goat, the only such complete study in any ruminant [2]. He also showed, most strikingly in the rabbit, that species differ markedly in the hormones necessary to support lactation [3]. Studies on the hormonal induction of lactation in mice picked up on the earlier studies of Lyons and continued for some time in Berkeley with work by Nandi $[4,5]$ in the Cancer 
Research Genetics Laboratory (CRGL). Ultimately the work in the CRGL moved mostly to a focus on breast cancer, but we reprint two additional articles from this laboratory in this issue $[6,7]$.

The early in vivo studies using endocrine ablation and replacement essentially form the basis for our understanding of the hormones that regulate mammary development and lactation. They were admirably summarized in a book by Cowie, Isabel Forsyth, and Ian Hart on the Hormonal Control of Lactation [8]. Sadly, this book is out of print and library copies are increasingly rare, but much of the material was summarized in a recent review [9].

One problem that was not resolved by the endocrine ablation and replacement studies described above was the question of the hormonal trigger for initiation of lactation at parturition (secretory activation). Nickolas J. Kuhn had been working with J.M. Lowenstein at Brandeis University on changes in the rat mammary gland around parturition. He noted that lactose was absent during pregnancy but increased to $13 \mu \mathrm{moles} / \mathrm{gm}$ tissue right at parturition, the most striking change of any of the mammary enzymes and constituents measured [10]. This change was not due to milk removal since no suckling had occurred prior to the sacrifice of the rats. It was shown in a subsequent paper to be due to a rapid increase in the activity of lactose synthetase [11], and much later to be due to an increase in the essential cofactor for lactose synthesis, $\alpha$-lactalbumin [12]. Kuhn was aware of the work of Halban in 1905 showing that both parturition and initiation of lactation were the result of the withdrawal of the hormones of pregnancy [13]. On this basis a number of scientists had postulated that the falling concentrations of progesterone led to an increase in secretion of the pituitary hormones involved in stimulation of milk secretion, as reviewed in the paper reproduced here [14]. In this paper, Kuhn gets right to the heart of the matter, as he always did, by ovariectomizing late pregnant rats and examining the change in lactose concentration in the mammary gland in the presence and absence of injected progesterone. Adequate doses of progesterone inhibited the increase in lactose. Measuring changes in glucocorticoids and the effects of prolactin convinced Kuhn and, in time, others that the essential lactogenic trigger is the fall in ovarian progesterone that initiates both parturition and milk secretion.

Current research is rightfully focused on the molecular mechanisms by which the developmental and lactogenic hormones act in both the normal mammary gland and breast cancer. The most important early article (1975) on this subject, reproduced here, was written by Jeffrey Rosen of Baylor College of Medicine, who continues as a leader in this field to this day. This article and the many that followed $[15,16]$ ushered in the molecular era in our understanding of the regulation of milk secretion. For an entrée into the current literature on this subject the reader is referred to several timely reviews in this journal [17-23] as well as key current articles [24-27].

\section{References}

1. Lyons WR, Li CH, Johnson RE. The hormonal control of mammary growth and lactation. Recent Prog Horm Res. 1958;14:219-48; discussion 248-54.

2. Cowie AT, Knaggs GS, Tindal JS. Complete restoration of lactation in the goat after hypophysectomy. J Endocrinol. 1964;28:267-79.

3. Cowie AT, Tindal JS. Effects of lesions of the pituitary stalk on lactation in the rabbit. J Endocrinol. 1975;66:115-21.

4. Nandi S. Endocrine control of mammary gland development and function in the $\mathrm{C} 3 \mathrm{H} / \mathrm{He} \mathrm{Crgl}$ Mouse. J Natl Cancer Inst. 1958;21:1039-63.

5. Nandi S. Role of somatotropin in mammogenesis and lactogenesis in C3H/He CRGL mice. Science. 1958;128:772-4.

6. Pitelka DR, Hamamoto ST, Duafala JG, Nemanic MK. Cell contacts in the mouse mammary gland. I. Normal gland in postnatal development and the secretory cycle. J Cell Biol. 1973;56:797-818.

7. Daniel CW, DeOme KB, Young JT, Blair PB, Faulkin LJ Jr. The in vivo life span of normal and preneoplastic mouse mammary glands: a serial transplantation study. Proc Natl Acad Sci USA. 1968;61:53-60.

8. Cowie AT, Forsyth IA, Hart IC. Hormonal control of lactation. Monogr Endocrinol. 1980;15:1-275.

9. Neville MC, McFadden TB, Forsyth I. Hormonal regulation of mammary differentiation and milk secretion. J Mammary Gland Biol Neoplasia 2002;749-66.

10. Kuhn NJ, Lowenstein JM. Lactogenesis in the rat. Changes in metabolic parameters at parturition. Biochem J. 1967;105:9951002.

11. Kuhn NJ. Lactogenesis in the rat. Metabolism of uridine diphosphate galactose by mammary gland. Biochem J. 1968;106:743-8.

12. Neville MC. Alpha-lactalbumin, a multifunctional protein that specifies lactose synthesis in the Golgi. J Mammary Gland Biol Neoplasia 2009;14 (this issue).

13. Halban J. Die innere Secretion von Ovarium und Placenta und ihre Bedeutung fuer die function der Milchdruese. Arch Gynaekol. 1905;75:353-441.

14. Kuhn NJ. Progesterone withdrawal as the lactogenic trigger in the rat. J Endocrinol. 1969;44:39-54.

15. Devinoy E, Houdebine LM. Effects of glucocorticoids on casein gene expression in the rabbit. Eur J Biochem. 1977;75:411-6.

16. Hennighausen LG, Sippel AE. Characterization and cloning of the mRNAs specific for the lactating mouse mammary gland. Eur J Biochem. 1982;125:131-41.

17. Trott JF, Vonderhaar BK, Hovey RC. Historical perspectives of prolactin and growth hormone as mammogens, lactogens and galactagogues - agog for the future!. J Mammary Gland Biol Neoplasia. 2008;13:3-11.

18. Oakes SR, Rogers RL, Naylor MJ, Ormandy CJ. Prolactin regulation of mammary gland development. J Mammary Gland Biol Neoplasia. 2008;13:13-28.

19. Huang K, Ueda E, Chen Y, Walker AM. Paradigm-shifters: phosphorylated prolactin and short prolactin receptors. J Mammary Gland Biol Neoplasia. 2008;13:69-79.

20. Brisken C, Rajaram RD. Alveolar and lactogenic differentiation. J Mammary Gland Biol Neoplasia. 2006;11:239-48. 
21. Howlin J, McBryan J, Martin F. Pubertal mammary gland development: insights from mouse models. J Mammary Gland Biol Neoplasia. 2006;11:283-97.

22. Kleinberg DL, Ruan W. IGF-I, GH, and sex steroid effects in normal mammary gland development. J Mammary Gland Biol Neoplasia. 2008;13:353-60.

23. Monks J. TGF $\beta$ as a potential mediator of progesterone action in the mammary gland of pregnancy. J Mammary Gland Biol Neoplasia. 2007;12:249-57.

24. Lydon JP, Edwards DP. Finally! A model for progesterone receptor action in normal human breast. Endocrinol. 2009;150:2988-90.
25. Graham JD, Mote PA, Salagame U, van Dijk JH, Balleine RL, Huschtscha LI, et al. DNA replication licensing and progenitor numbers are increased by progesterone in normal human breast. Endocrinology. 2009; 150:2988-90.

26. Fernandez-Valdivia R, Mukherjee A, Creighton CJ, Buser AC, Demayo FJ, Edwards DP, et al. Transcriptional response of the murine mammary gland to acute progesterone exposure. Endocrinology. 2008;149:6236-50.

27. Santos SJ, Haslam SZ, Conrad SE. Estrogen and progesterone are critical regulators of Stat5a expression in the mouse mammary gland. Endocrinology. 2007;149:329-38. 